\title{
Az információs társadalom. Az elmélettől a politikai gyakorlatig
}

\section{Szerzői információ:}

Mihály Emóke

Szociológus, az ELTE Társadalomtudományi Karán múködő Szociológiai Doktori Iskola elsôéves hallgatója. 2006-ban szerzett szociológusi diplomát a kolozsvári Babes-Bolyai Tudományegyetem Szociológia és Szociális Munkásképző Karán. 2007-ben ugyanott védte meg a Közpolitikák szociológiai alapjai témakörben készített magiszteri disszertációját. Érdeklốdési körei: a szegénységszociológia és a gazdaságszociológia területén belül a városi szegények alkalmazkodása a rendszerváltást követố gazdasági szerkezetváltozáshoz, a pénzhez való viszonyulásokon keresztül, valamint a fogyasztásszerkezet és a fogyasztói szokások.

E-mail: emokemihaly@yahoo.com

Így hivatkozzon erre a cikkre:

Mihály Emőke. „Az információs társadalom. Az elmélettől a politikai gyakorlatig”.

Információs Társadalom VIII, 1. szám (2008): 99-105.

— https://dx.doi.org/10.22503/inftars.VIII.2008.1.11

A folyóiratban közölt müvek

a Creative Commons Nevezd meg! - Ne add el! - Így add tovább! 4.0

Nemzetközi Licenc feltételeinek megfelelően használhatók. 


\section{OLVASÁS KÖZBEN}

Mihály Emoóke

\section{Az információs társadalom}

\section{Az elmélettól a politikai gyakorlatig}

Szerk.: Pintér Róbert

Budapest, 2007, Gondolat - Új Mandátum Könyvkiadó

A tankönyv, amelyre e recenzióban reflektálok, a NET-IS (Network for Teaching Information Society - Hálózat az információs társadalom tanításáért) nemzetközi projekt keretében született. Ahogyan a tankönyv elôszavában is olvashatjuk, a Leonardo da Vinci-program támogatásával megvalósult projekt célja egy információs társadalommal foglalkozó elektronikus tananyag kifejlesztése és tanítása több európai országban. Az információs társadalommal kapcsolatos ismeretek oktatását a tankönyv mellett szöveggyújtemény, tanulási program, CD-ROM, vegyes oktatási formákban szervezett (blended learning) kurzusok, valamint speciális módszertan és e-learning céljára kidolgozott tananyagok segítik.

A társadalomtudományi szemléletú tankönyv célja az elméleti alapok és az információs társadalom kiépítését szolgáló politikai gyakorlatok általánosabb nézôpontok szerinti megismertetése, az érdeklő́dó olvasók és az egyetemi, fóiskolai hallgatók sikeres bevezetése az információs társadalom témakörébe. Általánosabb nézőpontok felól közelít, hiszen célja, hogy szinte minden szakon tanítható anyagot foglaljon össze, nem csupán Magyarországra koncentrálva, hanem nemzetközi kitekintéssel.

A 246 oldalas tankönyv tizenhárom fejezetból áll, amelyek nagyobb témákat, részterületeket dolgoznak fel. Az első két fejezetben az információs társadalom fogalmával, elméletével és történetiségével (Pintér Róbert, 'Z. Karvalics László), a következókben pedig a technológia és a társadalom kölesönhatásaival (Kincsei Attila), a hálózati társadalom és a hálózati gazdaság kérdéskörével (Molnár Szilárd - Kollányi Bence - Székely Levente), a térhasználathoz és a térhez kapcsolódó társadalmi viszonyokkal (Kollányi Bence), az innovációk szerepével (Holczer Márton), jogi-szabályozási kérdésekkel (Simon Éva), az Európai Unió információs politikájával és stratégiáival (Juhász Lilla), az elektronikus kormányzattal és adminisztrációval (Molnár Szilárd), a digitális megosztottsággal és az e-esélyegyenlőséggel (Elisa Mancinelli), a digitális kultúrával és a kulturális örökség digitalizálásával, az információs írástudással (Rab Árpád) s végül az elektronikus oktatás és az egész életen át tartó tanulás témakörével (Bessenyei István) ismerkedhetünk meg.

Az információs és kommunikációs eszközök, az információs technológiák terjedése és maga az információs társadalom nem képezi tudományos érdeklődésem tárgyát: ezek az eszközök inkább a mindennapi környezetemben jelennek meg, hiszen aktív felhasználó vagyok. Így e könyvet tanulóként vettem a kezembe, és a tanuló szemüvegén keresztül fogalmazom meg tapasztalataimat. 
A tankönyvet Pintér Róbert Úton az információs társadalom megismerése felé címú fejezete nyitja, ezt követi Z. Karvalics László Információs társadalom - mi az? Egy kifejezés jelentése, története és fogalomkörnyezete címú fejezete. Az elsó két fejezet az információs táradalom fogalmát ízlelgeti. Az információs társadalom bevezetô diskurzusainak tárgyalása során megtudjuk, hogy mennyire megalapozottak az internettel kapcsolatos félelmek és elóítéletek. Megismerjük a futurológusok és a „földhözragadtak” álláspontját a technológiával kapcsolatban, azzal a szerzói figyelmeztetéssel, hogy hiba elvárni a technológiai fejlődéstól a társadalmat mélyen megrengetô változásokat. Az „Athén vagy Orwell?" diskurzus tárgyalása során megismerkedünk a technofil és a technofób tábor szélsốséges vízióival, valamint a felmerüló félelmeket enyhítố technorealizmus fogalmával (,a technológiát kezeljük a maga tényleges értékén”, „még több technológia nem egyenlő még jobb vagy minőségileg más társadalommal”) (18). Pintér az elsố fejezetben a fogalmak egyszerú megközelítésével törekszik bemutatni, hogy mit jelent az információ és mit a társadalom, s a két fogalom együtt milyen jelentést kap. A különbözó társadalomtudományi megközelítések megismerése révén rálátunk azokra a technológiai, foglalkozásszerkezeti, gazdasági, térszerkezeti és kulturális változásokra, melyeknek köszönhetôen a mai társadalomról mint információs társadalomról beszélhetünk. Karvalics a második fejezetben először az „előfogalmakra” és egyes részfogalmakra tér ki, majd az információs társadalom fogalmát többdimenziós elemzéssel határozza meg. Az erre vonatkozó modellekhez (Bell [1979], Masuda [1988], Schement és Curtis [1997], 35-37) képest a szerző modellje azokra az átbillenési pontokra fókuszál, amelyek elérésétól egy társadalom információs társadalommá válik, azaz a társadalom minốségileg megváltozik. Karvalics foglalkozásszerkezeti és gazdasági szempontú megközelítésben beszél az információs társadalomról, hiszen ma már az információs szektor és az információs jellegú munkavégzés dominál a gazdaságban. Végül bemutatja az információs társadalom irodalmának három vizsgálati rendszerszintjét, az egymással összefüggó mikro- („mininarratíva”, praxis és reflexió), mezo- („,kis narratíva”, fejlődéselmélet) és makroszintú („,nagy narratíva”, civiliációelmélet) diskurzusokat. Hangsúlyozza, hogy az információs társadalom „klasszikus” narratívája a civilizációelméleti szint, s felsorolja annak sarkalatos kérdéseit is.

Kincsei Attila fejezete ('Téchnológia és társadalom az információ korában) a technológia és társadalom kapcsolatával, az információs és kommunikációs technológiáknak (IKT) a társadalmi változásokban betöltött szerepével foglalkozik. A fejezet célja a társadalom és a technológia kölcsönhatásaival kapcsolatos fogalmak, modellek és elméletek bemutatása. A technológiai determinizmus irányzata mellett Kincsei röviden ismerteti az innovációk diffúzójának elméletét, valamint a tudomány és a technológia fejlődésének társadalmi meghatározottságát hangsúlyozó elméleteket: a „technológia társadalmi felépítését" valló irányzatot (Social Construction of Technology, SCOT), az ún. „cselekvő-hálózat-elméletet” (Actor-Network-Theory, ANT) és a rendszerszemléletú technikatörténeti megközelítést. Röviden arról is szól a szerző, hogy az elméletek alkalmazásának milyen nehézségei, hiányosságai lelhetók fel. Ki kell emelnem mint pozitívumot az elméletek könnyebb megértéséhez felhozott példákat, hiszen tanulóként ezek révén nyertem világos és érthetô képet a kibontott elméletekról. Viszont e fejezet kereteiben szívesen olvastam volna még valamiról, amielyre a szerzố nem tér ki, nevezetesen arról, hogy hol tart az Európai Unió a technológiai fejlődés szempontjából a köz- 
beszédben sokat emlegetett Egyesült Államokhoz képest, valamint az Unióhoz újonnan csatlakozott közép- és kelet-európai országok hol tartanak a fejlettebb NyugatEurópához viszonyítva. A fejezet végén már utal a szerző arra, hogy a „hálózat” és a „hálózatiság” fogalmai Castells múveiben mint a társadalom megváltozott múködési módjának meghatározó jellegzetességei jelennek meg (61). Ezzel a témával mélyrehatóbban azonban a következó fejezet foglalkozik.

Míg Kincsei fejezete az IKT-eszközök kapcsán technikai szempontból utalt az új hálózatok kialakulására, addig a következó fejezet (Molnár et al.: Társadalmi hálózatok, hálózati társadalom) azt vizsgálja, hogy az internet és általában az új hálózatok miként hatnak a társadalmi integrációra, a kisközösségek kohéziójára, az egyén társas viszonyaira. Molnár és társai a hálózati társadalom fogalomrendszerét egyetlen szerzóre, Castellsre utalva járják körül. Az ezzel összefüggő további fogalmak (társadalmi hálózatok, társadalmi tốke, hálózati gazdaság) rövid vázolása után a kapcsolódó elméletek bemutatása következik. A kiinduló kérdés itt az, hogy az egyre inkább hálózatszerúen múködő́ információs társadalomban az internet mint izoláló technológia vagy pedig mint egyre fejlettebb kommunikációs lehetôség jelenik-e meg. A témára vonatkozó különböző kutatásokat és elméleteket nagyon jól foglalják össze a szerzók, azonban az olvasó számára nem derül ki, hogy milyen álláspontot képviselnek ók maguk az általuk felvetett kérdésekben. A társas kapcsolatok és az internetezés kapcsán nem említik a különböző online szerepjátékok (például az MMORPG - Massively Multiplayer Online Role-playing Game - vagy a Word of Warcraft) fontosságát. A következő fejezetben (Térhasználat az információs társadalom korában) Kollányi Bence térszerkezeti megközelítésben vizsgálja az információs társadalmat. Bemutatja, hogy a földrajzi felfedezések korában hogyan tágult ki a tér, majd a közlekedés és IKT-eszközök elterjedésével hogyan vált egyre szúkebbé. Az új térformákkal kapcsolatban kitér a kibertér fogalmára, valamint a virtuális valóság elốzményeire, illetve fóbb alkalmazási területeire. Felsorolja a „virtuális valóság” néhány praktikus felhasználási lehetôségét (terápiás alkalmazások, elektronikus kormányzati szolgáltatások), az online szerepjátékok kapcsán viszont figyelmen kívül hagyja azok negatív hatásait. ' Ez a fejezet ráirányítja a figyelmünket arra, hogy az információs technológiák és a globalizáció következtében egyre kevésbé meghatározó a fizikai tér szerepe, hiszen hálózatok vesznek körül bennünket, amelyek új keretet adnak a társadalmi folyamatoknak. A globalizációs folyamatokkal és a térhasználattal összefüggésben taglalja a nemzetközi vállalatok stratégiáit, az egész Földre kiterjedő termelési és értékesítési módokat, a globális munkamegosztás alapjait. A globalizáció, a gazdasági fejlốdés és a térszerkezet átalakulása kapcsán viszont nem kerül szóba egy ezekkel szorosan összefüggó folyamat: a lokalizáció felerósödése, az ún. globális-lokális paradoxon.

Az Innovációs verseny és információs társadalom címú fejezetben Holczer Márton az innováció és az innovációs verseny témáját járja körül. Természetesen először az innováció fogalmával, meghatározásával és fóbb típusaival ismerkedünk meg, a könnyebb megértést példák segítik. A fogalmak tisztázását a különféle innovációs modellek (lineáris modell, láncszemmodell, zárt innovációs lánc) bemutatása követi. Az innovációra

${ }^{1}$ A médiában is gyakran tárgyalt téma az egyre elterjedtebb online játékfüggés és annak lehetséges negatív hatásai. 
való képesség a vállalatok versenyképessége szempontjából kap nagy hangsúlyt, hiszen a fejlesztés gyorsasága az egyik legfontosabb versenyképességi tényezô. A versenyképesség és a termelékenység fokozásában fontos szerep jut a kutatásnak és a fejlesztésnek $(\mathrm{K}+\mathrm{F})$, valamint az IK'T felhasználásának. Egyre gyakoribb jelenség, hogy a vállalatok az IK'T-nek köszönhetốen a székhelyüktól távoli helyszíneken építik ki K + F bázisaikat. Összegezve, a szerző szerint a siker kulcsa az, ha egyidejúleg és egyazon helyszínen rendelkezésre állnak a következô feltételek: megfelelő jogi szabályozási környezet, hozzáférhetơ kockázati tóke, fejlett pénzügyi rendszer, világszínvonalú K + F bázisok, a kormányzat segítókészsége, valamint a kulcsszereplók bizalma és kooperációs képessége. További fontos megállapítás, hogy ha a különbözố térbeli helyszínek nem a globálisnak tekintett világgazdasági-technológiai trendek mentén találják meg saját kitörési pontjaikat, akkor gazdasági jelentôségük folyamatosan csökkenni fog. A jól strukturált fejezet magyarázatokkal, példákkal alátámasztva bốvíti ismereteinket az innováció témakörében, azonban a további ismeretszerzéshez a tanulmány végén felsorolt irodalom eléggé szegényes.

Az eddigi tárgyalt fejezetek fớként az elméletek szintjén szolgáltattak ismereteket az információs társadalomról. A továbbiakban a politikai gyakorlatok bemutatására kerül a hangsúly. Simon Éva fejezete (Bevezetés az információs társadalom jogi szabályozásába) az internetre fókuszálva a jogi szabályozások általános elméleti és gyakorlati kérdéseivel foglalkozik. A fejezet sokat segít a szabályozás kereteit meghatározó uniós jogfejlesztési elvek és a globális szabályozási törekvések megértésében. Megismerkedünk „az információs társadalom joga” kifejezéssel, s ezen belül a kétféle (ex ante, ex post) szabályozási módszerrel, továbbá az önszabályozás fogalmával. A fogalomtisztázást követôen a szerzô három rivális irányzatot mutat be az információs társadalom szabályozásával kapcsolatban: a jogmentes tér mítoszát (ehhez kapcsolódik a felhasználók által kialakított „netikett”), az internetet speciális szabályozási térnek, szuverén államnak tekintô felfogást, valamint az integrált szabályozás irányzatát, amely szerint a már létezố jogszabályok alkalmazhatók az internetre. Az utóbbi tekinthetó a gyoózedelmeskedô paradigmának: a már meglévố normák vonatkoznak az információs társadalomra is, speciális szabályozásra pedig csak akkor van szükség, amikor eddig ismeretlen jogi kérdések jelennek meg (például digitális aláírás, elektronikus információszabadság). Az információs társadalom valamennyi szabályozási kérdésének bemutatására a fejezet kereteiben nyilván nincs lehetôség, azonban megismerkedhetünk három lényegesen eltérô szabályozási modellel: az audiovizuális média szabályozásával, a személyes adatok védelmével és az információszabadsággal. A szövegben és a lábjegyzetekben bőven találunk példákat, ami midenképpen dicséretes, viszont nem tér ki a szerzó arra, hogy az Unió tagállamaiban elfogadott irányelvek és törvények mennyire jelennek meg a hétköznapok szintjén, fóként a volt szocialista országokban, ahol például, az információszabadságról szóló törvényt késóbb fogadták el, mint a többi tagállamban.

A következố fejezetben Juhász Lilla Az Európai Unió információs stratégiája címmel az Unió különbözó programjait és terveit ismerteti. Nyomon követi az Európai Unió információs politikáját az elsôsorban gazdasági kérdéseket szem elótt tartó Bangemann-jelentéstól (1994) az eEiurope programokig. Megtudjuk, hogy a kezdeti, csupán gazdasági szempontok alapján kijelölt fejlesztési feladatok mellett az 1999-es évektól egyre hangsúlyosabbá válnak a társadalmi szempontok („Információs társada- 
lom mindenkinek!”). Az 1999 és 2005 közötti eEurope programok már az internet fejlesztésére koncentrálnak, mivel ezen a területen észlelték az Unió legnagyobb lemaradását a versenytársakhoz képest. Az eE urope + 2003 program kiterjeszti a célkitúzéseket az újonnan csatlakozó országokra, fóként a digitális megosztottság minimalizálására koncentrálva. Hogy ez a program az új tagállamokban mennyire jár sikerrel, arra nem tér ki a szerzố. Az eE Erope programok átfogó célja végsố soron az Unió versenyképességének növelése, a tudásalapú gazdaság megteremtése, a szociális kohézió, valamint a foglalkoztatottság növelése: e célok elérésére a 2010. évet jelölték meg. Az i2010 kezdeményezés újabb stratégiaváltást jelent: ennek központi célkitúzése az egységes információs tér megteremtése, a kutatás és fejlesztés támogatása, a mindenkit befogadó információs társadalom kiépítése. Az Unió politikai gyakorlata tehát a központi, szupranacionális szinten elfogadott célkijelölés és programalkotás, illetve a nemzeti szintû akciótervek kettốs alapjára épül. Azt még megtudjuk a fejezetból, hogy a tagállamok különbözó mértékben valósítják meg a kitúzött célokat, de hogy az egyes országok ebben mennyire sikeresek, mennyire tudnak vagy nem tudnak megfelelni a követelményeknek, arra nem kapunk választ.

Molnár Szilárd a soron következő fejezetben (E-köæigazgatás aะ Európai Unióban) az elektronikus közigazgatás témájával foglalkozik. Az e-közigazgatási koncepciók középpontjában is a versenyképesség növelése áll, amihez átlátható közigazgatásra van szükség. Az Unió törekvéseiben az online közszolgáltatások kiépítése terén az állampolgár-központú szemlélet dominál: a szerzố részletesen taglalja a 2010-ig kitúzött konkrét célokat és ismerteti az elektronikus közigazgatás jellemzóit, valamint annak elönyeit az állampolgárok, a vállalkozások és a közhivatalok szempontjából egyaránt. Megismerhetjük továbbá a benchmarking módszerét, amellyel az elért eredményeket, illetve a hiányosságot mérik a tagállamokban. Szemléletes ábrákkal, táblázatokkal mutatja be a szerző az e-közigazgatási fejlődés eredményeit az Unió országaiban, az e-kormányzatra irányuló kutatások fejlốdését és a különféle vizsgálatok, hatásfelmérések új irányait, röviden kitérve az e-közigazgatás lehetséges hátrányaira is.

Elisa Mancinelli E-befogadás a: információs társadalomban címú fejezete az Európai Unió e-befogadási politikáját tárgyalja. Az alapfogalmak (társadalmi kirekesztés, társadalmi befogadás, digitális megosztottság) tisztázását rövid elméleti rész követi, majd az Unió politikai programjainak fejlő́dését mutatja be a szerzô. Az e-befogadás fontossága újra csak a versenyképességgel áll szoros kapcsolatban, megfeleló múködéséhez viszont az IK'T-eszközöket felhasználó, aktív állampolgári közösségekre van szükség. Az új technológiákat illetốen az állampolgárok körében háromféle szemlélet tapasztalható: az elsố szerint a hátrányos helyzetúek nem képesek hozzáférni az új technológiákhoz, a második szerint az új technológiák óriási lehetôséget jelentenek a társadalmi kirekesztés problémáinak megoldására, a harmadik szerint pedig az emberek az új technológiák segítségével kiszabadulhatnak az „öröklött szegénység” csapdáiból. A szerzố részletesen bemutatja az Uniónak a digitális megosztottság leküzdésére és az e-befogadás elósegítésére irányuló politikáját, megjegyezve, hogy az Unió elkötelezte magát a befogadó információs társadalom kiépítése mellett, és kijelölte a teendóket is: most már a tagállamok feladata, hogy érvényt szerezzenek ennek a politikának.

Rab Árpád fejezete a digitalizált és digitális úton létrejött kultúrával foglalkozik (Digitális kultúra - A digitalizált és a digitális platformon létrejött kultúra). A jól felépített fe- 
jezet elsố részében az információs írástudással, e fogalom rövid történetével és különböző értelmezéseivel, továbbá az idesorolható készségekkel és azok eltérô szintjeivel ismerkedünk meg. A második rész a kulturális örökség digitalizálását és ennek a funkcióit, a harmadik pedig a digitális kultúra témakörét tárgyalja. A téma fontosságát mutatja, hogy az Európai Unióban - csakúgy mint világszerte más régiókban is - állami projektek keretében folyik a kulturális örökség digitalizálása, a kulturális versenyképesség gazdasági hajtóeróként való felhasználása érdekében. Itt nem beszél a szerzô az Unióban folyó programokról, például az európai digitális könyvtár létrehozásáról szóló tervekról. A digitalizálásban rejló lehetôségek a megốrzés és tárolás mellett fóként az analóg gyứjtemények digitalizálásával, az online hozzáférhetôség biztosításával aknázhatók ki: a digitális kultúra kialakulásával az alapmúveltség átalakul globális szintú, multimediális tapasztalati és ismeretvagyonná. A szerző felhívja a figyelmet a digitális kultúra negatív hatásaira is. Rámutat, hogy újabb rétegkülönbségek jönnek létre a társadalomban, álláspontja szerint azonban „,a negatív jelenségek a technikai korlátok miatt alakultak ki”, és itt nem csupán „összekapcsolt számítógépek” és „halott információk” hálózatáról, hanem „éló emberek és az óket érdeklő tudáselemek hatalmas, innovatív, dinamikus hálózatáról van szó" (199).

Bessenyei István a következő fejezetben az elektronikus oktatás és az egész életen át tartó tanulás témájával foglalkozik (Tanulás és tanítás a: információs társadalomban. Az eLearning 2.0 és a konnektivizmus). Bemutatja a hagyományos társadalmak tanulási módját, majd a reformpedagógián keresztül eljut a hálózatba szervezett tanulás formáinak és sajátosságainak részletes ismertetéséig (eLearning 0.1, eLearning 0.2, konnektivizmus), a tanulást segítô szoftverekig (Web 1.0, Web 2.0) és az internetig mint az egyéni tanulás központi forrásáig. Megtudjuk, hogy az új tanulásszervezési elméletek szerint a hálózati tanulás megszüntetheti a modernitás korára jellemzố szétszabdaltságot és az újraintegráltság eszközévé válhat. Az új tanulási formák természetesen megkérdôjelezik a hagyományos oktatási intézmények szerepét, és ahogyan azt a szerzố is hangsúlyozza, az új formák terjedése sok konfliktust generálhat, hiszen ezek nehezen illeszthetók be a hagyományos intézmények keretei közé. Ugyanakkor az eLearning bevezetése kapcsán nem beszél a szerzố a tagállamokban ezen a téren már megvalósult konkrét gyakorlatokról, az elért eredményekról és az eddig szerzett tapasztalatokról.

A tankönyvet Pintér Róbert fejezete zárja (Divatos hivósঞavak, nagy elméletek, fejlesztési szupernarrativák és metanarrativák - Az információs társadalom jelentésvilága), amelyben a kötet szerkesztóje kifejti a tankönyv felépítésekor követett szempontokat. Az információs társadalom megközelítéseinek és értelmezéseinek rövid összegzése révén láthatjuk, hogy az „információs társadalom” nem egzakt fogalom, hanem felfogható „utópiaként, valóságként, technológiai forradalomként, tudományos vizsgálódás tárgyaként, politikai programként, metanarratívaként vagy szupernarratívaként, 21. századi hétköznapjaink kereteként vagy új társadalmi korszakként” (221).

Elmondhatom, hogy a tankönyv elérte célját: olvasmányos stílusának köszönhetốen diákok, tanárok, kutatók, szakértók és a terület iránt érdeklődő, de mindenféle elözetes szakmai felkészültséget nélkülözô laikusok egyaránt elolvashatják. A fejezetek szerzối nem bonyolódnak elméleti útvesztốkbe, tárgyalásmódjuk nem túlságosan elméleti vagy elvont, és az elméleti kérdések mellett a gyakorlati problémákba is betekintést adnak. A „moduláris” felépítés igen szerencsés, mert ennek köszönhetóen az olvasónak 
lehetôsége nyílik csak a kívánt fejezetet elolvasni és megérteni, anélkül, hogy az egész könyvet át kellene lapoznia. A dicséretesen olvasóbarát felépítéshez további segítségként hozzájárulnak a fejezetek végén található rövid tartalmi összegzések, a tárgyi tudást ellenőrző kérdések és az egyes témák szerinti bontásban megadott irodalom is. A szövegben vastagon szedett, kiemelt fontosságú fogalmak és szakkifejezések definícióját megtaláljuk a könyv végén, viszont hiányolom a név-és tárgymutatót, amely lehetôvé tenné a témával kapcsolatos kifejezések keresését a szövegben. A könyv másik hiányosságaként említem, hogy nem olvashatunk információkat a fejezetek szerzóiról.

Összességében kiemelném, hogy a tankönyv érthetô, olvasmányos, és sokat tanulhatunk belóle. Mindazon érdeklődók figyelmébe ajánlom, akik alapvető ismereteket szeretnének szerezni az információs társadalomról. 